\title{
Severe hereditary thrombophilia due to congenital protein C deficiency
}

INSERM

\section{Source}

INSERM. (1999). Orphanet: an online rare disease and orphan drug data base. Severe hereditary thrombophilia due to congenital protein C deficiency. ORPHA:745

Congenital protein $\mathrm{C}$ deficiency is an inherited coagulation disorder characterized by deep venous thrombosis symptoms due to reduced synthesis and/or activity levels of protein C. 